\title{
Analisa pengaruh sudut sudu terhadap kinerja turbin kinetik poros horisontal dan vertikal
}

\author{
Yasinta Sindy Pramesti \\ Program Studi Teknik Mesin, Universitas Nusantara PGRI Kediri \\ E-mail: yasintasindy@ unpkediri.ac.id
}

\begin{abstract}
Abstrak
Turbin kinetik adalah suatu jenis pembangkit listrik yang memanfaatkan energi yang tersimpan pada aliran air yaitu energi potensial dan energi kinetik yang akan diubah menjadi energi mekanik . Salah satu faktor yang mempengaruhi kinerja turbin yaitu sudut sudu. Metodologi penelitian pada turbin kinetik ini memanfaatkan kecepatan fluida (air) yang bergerak dengan. Variasi sudut pengarah aliran dengan sudut yang akan diteliti ini menggunakan sudut $5^{\circ} 10^{\circ}, 15^{\circ}$ dan variasi debit aliran 50, 70 dan $90 \mathrm{~m}^{3} / \mathrm{jam}$. Selain itu, turbin kinetik ini menggunakan variasi poros vertikal dan horizontal. Berdasarkan hasil penelitian, maka dapat disimpulkan bahwa daya output yang dihasilkan turbin maksimal sebesar 1,53 Watt terjadi pada debit $90 \mathrm{~m} 3 /$ jam dengan sudut pengarah aliran $15^{\circ}$. Efisiensi tertinggi yaitu sebesar $18 \%$ terjadi pada debit aliran $50 \mathrm{~m} 3 / \mathrm{jam}$ dengan sudut pengarah aliran sebesar $15^{\circ}$. Turbin dengan tipe poros horizontal memiliki nilai daya dan efisiensi yang sedikit lebih besar jika dibandingan dengan turbin poros vertikal.
\end{abstract}

Kata Kunci: turbin kinetik, sudut sudu, poros vertikal, poros horizontal.

\section{Abstract}

Kinetic turbine is a type of power plant that utilizes the energy stored in the water flow ie potential energy and kinetic energy that will be converted into mechanical energy. One of the factors that affect turbine performance is angle angle. The research methodology in this kinetic turbine utilizes the fluid velocity (water) that moves with. The variation of the flow steering angle with the angle to be studied uses an angle of 5 ${ }^{\circ} 10^{\circ}, 15^{\circ}$ and flow rate variation 50,70 and $90 \mathrm{~m}^{3} / \mathrm{hr}$. In addition, this kinetic turbine uses vertical and horizontal axis variations. Based on the result of the research, it can be concluded that the maximum output power produced by turbine at 1.53 Watt occurred at $90 \mathrm{m3} / \mathrm{hr}$ discharge with flowing direction angle of $15^{\circ}$. The highest efficiency of $18 \%$ occurs at a flow rate of $50 \mathrm{m3} / \mathrm{h}$ with a flow direction angle of $15^{\circ}$. Horizontal axle turbines have slightly higher power and efficiency values when compared to a vertical axle turbine.

Keywords: kinetic turbine, sudu angle, vertical shaft, horizontal shaft.

\section{PENDAHULUAN}

Indonesia memiliki energi air yang sangat melimpah dan tersebar diseluruh wilayahnya. Menurut Direktur Konstruksi dan Energi Terbarukan, PT. PLN, Indonesia memiliki potensi air sekitar 75.000 - 76.000 MW. Tetapi pemanfaatannya masih sekitar 3.783 MW untuk skala besar dan 220 MW untuk skala kecil [1]. Salah satu energi air skala kecil adalah arus sungai yang mempunyai kecepatan rendah berkisar 0,01-2,8 m/s dan energi tersimpan di dalamnya dapat digunakan sebagai energi listrik dengan menggunakan turbin kinetik. Turbin kinetik adalah suatu 
pembangkit listrik yang prinsip kerjanya memanfaatkan dan mengandalkan energi kinetik air sebagai sumber energinya dalam merubah energi potensial dan energi kinetik menjadi energi mekanik.Arus aliran air langsung menumbuk sudu turbin yang dapat menyebabkan runner berputar sehingga terjadi perubahan energi kinetik air menjadi energi mekanis pada turbin yang digunakan untuk menggerakkan generator kemudian menjadi energi listrik [2,3]. Keuntungan pemanfaatan turbin kinetik jika dimanfaatkan sebagai pembangkit listrik yaitu pemilihan lokasi tidak terlalu banyak syarat dan tanpa bendungan, instalasi yang murah dan waktu pemasangan

Turbin kinetik adalah suatu jenis pembangkit listrik yang memanfaatkan energi yang tersimpan pada aliran air yaitu energi potensial dan energi kinetik yang akan diubah menjadi energi mekanik. Proses perubahan energi kinetik pada aliran air menjadi energi mekanik berawal dari arus aliran air yang menyimpan energi mekanik menumbuk sudut turbin yang dapat menyebabkan turbin berputar sehingga terjadi perubahan energi kinetik menjadi energi mekanik pada turbin yang akan digunakan untuk memutar generator dan akan diubah menjadi energi listrik oleh generator tersebut. Penggunaan turbin air, khususnya turbin kinetik jenis ini dengan memanfaatkan aliran sungai yang kecil belum meluas karena selain masalah biaya juga bagaimana meningkatkan kinerja dari turbin baik dari segi aliran fluida maupun dari konstruksi turbin itu sendiri. Berbagai penelitian telah dilakukan untuk mempercepat aliran dengan mengatur dimensi saluran masuk turbin maupun bentuk sudu.

Kinerja dari suatu turbin kinetik bergantung pada kecepatan aliran, sudut sudu, pengarah aliran, ukuran aliran, jumlah sudu, dan kelengkungan pada sudu. Sudut pengarah aliran turbin kinetik adalah salah satu variabel yang sangat mempengaruhi putaran dan gaya tangensial yang menentukan daya dan efesiensi sebuah turbin kinetik. Oleh karena itu, penelitian ini diarahkan untuk menentukan sudut pengarah aliran yang ideal dengan kecepatan yang divariasikan dalam menghasilkan daya turbin yang maksimal. Tujuan dari penulisan ini adalah mengetahui pengaruh sudut sudu terhadap kinerja turbin kinetik tipe poros vetikal dan horizontal.

Turbin kinetik adalah suatu turbin yang menghasilkan energi mekanik berupa putaran poros. Turbin ini mengandalkan kecepatan aliran air dan memanfaatkan energi kinetik air. Selanjutnya energikinetik tersebut diubah menjadi energi mekanik yang digunakan untuk menggerakkan sudu generator sehingga menghasilkan energi listrik. Turbin ini sangat tepat untuk dipakai pada daerah yang datar yang memiliki aliran sungai, terutama daerah pedesaan. Sampai saat ini dikenal dua jenis turbin kinetik, yaitu turbin kinetik dengan poros horizontal dan turbin kinetik berporos vertikal [4].

Pada turbin kinetik vertikal (tegak) air langsung menumbuk sudu pada setengah bagian roda turbin sedangkan setengah bagian yang lain juga mendapat tumbukan tetapi tidak sebesar setengah bagian yang pertama sehingga turbin masih bisa berputar [5]

Warsito dkk [6] menyatakan bahwa banyak keuntungan yang diperoleh apabila turbin kinetik ini dipergunakan sebagai pembangkit listrik. Keuntungan pemanfaatan turbin kinetik adalah :

a. Tanpa reservoir

b. Pemilihan lokasi tidak terlalu banyak syarat

c. Tanpa bendungan dan power house 
d. Instalasi yang murah

e. Waktu pemasangan yang cepat

f. Modular, keluaran energi yang mudah di skala (easily scalable energi output)

g. Kapasitas yang stedy, produksi energi yang steady.

h. Bentuknya sederhana dan mudah dibuat.

i. Potensi air yang dibutuhkan tidak membutuhkan tinggi jatuh, yang dibutuhkan hanya adanya aliran air (Energi kinetik $=v 2 / 2 \mathrm{~g}$ ).

j. Tegangan listrik yang dibangkitkan adalah $24 \mathrm{~V}$ DC.

k. Pemeliharaan mudah.

1. Turbin hanya diletakkan pada aliran sungai, dan tidak membutuhkan bangunan khusus.

Untuk setiap aliran sungai dapat dipasang beberapa instalasi turbin kinetik ini. Sehingga listrik yang dibangkitkan akan berlipat sesuai dengan banyaknya turbin yang dipasang pada aliran sungai tersebut.

\section{METODE PENELITIAN}

Penelitian pada turbin kinetik sudu turbin sebagai obyek utama yang diteliti. Turbin kinetik yang bekerja pada aliran air yang memanfaatkan kecepatan fluida (air) yang bergerak tanpa menggunakan nozzel atau air jatuh, tetapi menggunakan sungai buatan sebagai tempat turbin yang akan diteliti. Sudut pengarah aliran sebagai obyek utama dalam penelitian ini dan akan difokuskan pada penggunaan sudut pengarah aliranuntuk mencari pengaruh penggunaan sudut pengarah aliran pada kinerja turbin. Variasi sudut pengarah aliran sudut yang akan diteliti ini menggunakan sudut $5^{\circ} 10^{\circ}$ dan $15^{\circ}$ dengan variasi debit aliran 60,80 dan 100 $\mathrm{m}^{3} / \mathrm{jam}$.

Faktor-faktor yang mempengaruhi kinerja dari sebuah turbin kinetik yang menggunakan sudu mangkuk sebagaimana dijelaskan pada Gambar 1.

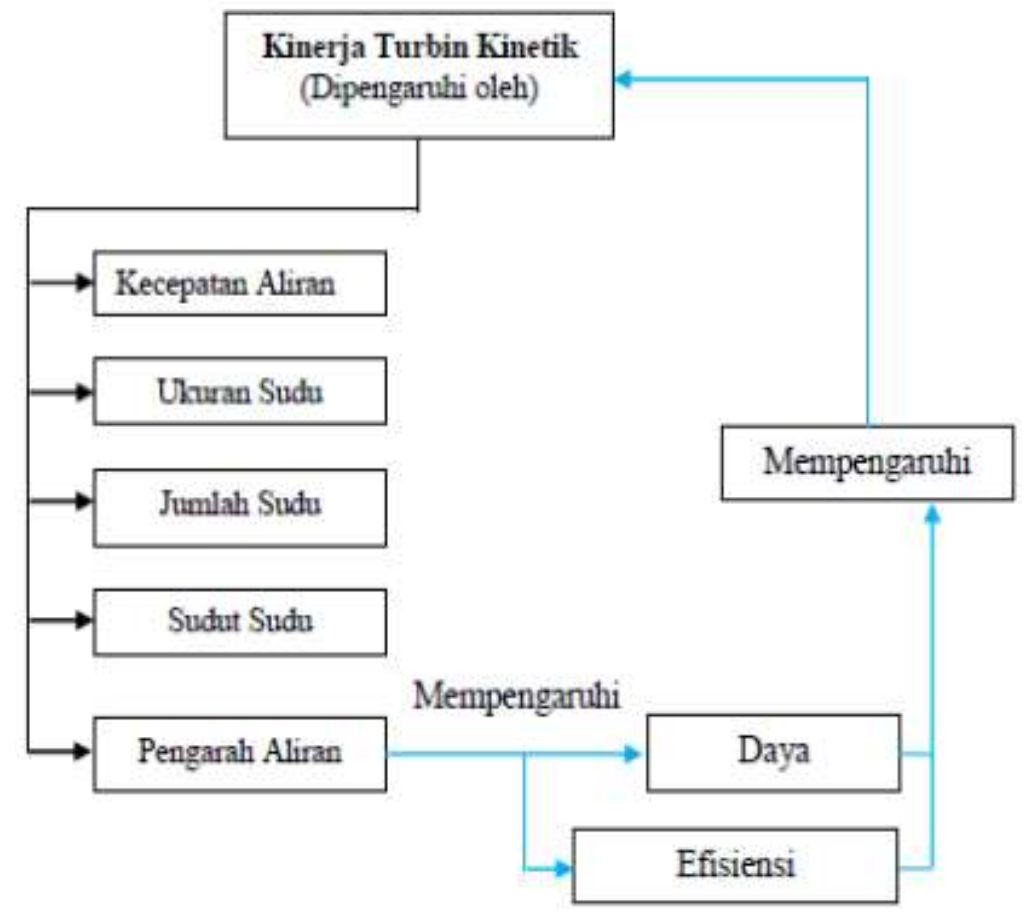

Gambar 1. Diagram Faktor-faktor yang Mempengaruhi Kinerja Turbin Kinetik 
Secara umum, tahapan-tahapan penelitian ditunjukkan pada diagram alir Gambar 2 berikut.

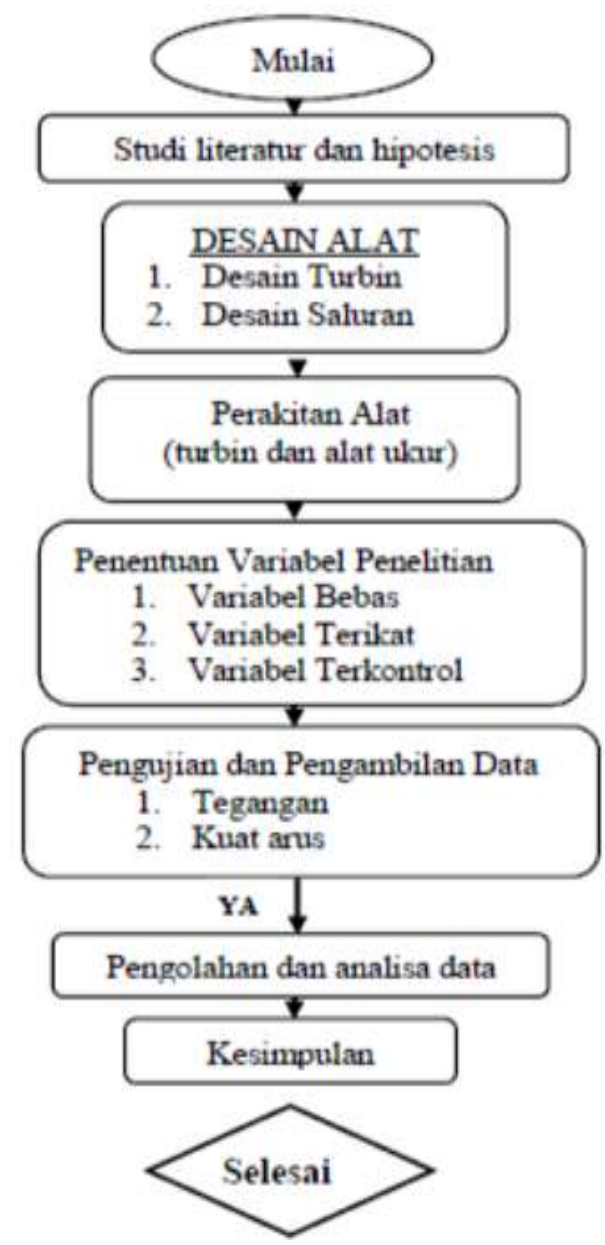

Gambar 2. Diagram Alir Tahapan Penelitian

Dalam penelitian ini variabel yang digunakan ada tiga jenis yaitu variabel bebas, variabel terikat dan variabel kontrol.

1. Variabel Bebas

Variabel bebas adalah variabel yang nilainya ditentukan secara bebas sebelum penelitian dilakukan. Variabel bebas dalam penelitian ini variasi sudut pengarah aliran yaitu : $5^{\circ}, 10^{\circ}, 15^{\circ}$ dan debit aliran $50 \mathrm{~m} 3 / \mathrm{jam}, 70 \mathrm{~m} 3 / \mathrm{jam}$ dan $90 \mathrm{~m} 3 / \mathrm{jam}$.

2. Variabel Terikat

Variabel terikat adalah variabel yang nilainya tergantung pada variabel bebas dan merupakan hasil dari penelitian. Dalam penelitian ini variabel terikat yang diamati yaitu daya dan efisiensi turbin.

\section{Variabel Kontrol}

Variabel kontrol adalah variabel yang dikendalikan atau dibuat konstan sehingga hubungan dependen tidak dipengaruhi oleh faktor luar yang tidak diteliti. Jadi variabel kontrol dalam penelitian ini adalah panjang saluran kanal $700 \mathrm{~cm}$ dan panjang pengarah aliran $60 \mathrm{~cm}$. 


\section{HASIL DAN PEMBAHASAN}

Bagian ini menyajikan hasil penelitian dan pembahasan yang ditulis ringkas. Hasil penelitian dapat disajikan dengan dukungan tabel, grafik atau gambar sesuai kebutuhan, untuk memperjelas penyajian hasil secara verbal. Bagian pembahasan memaparkan hasil pengolahan data, menginterpretasikan penemuan secara logis, mengaitkan dengan sumber rujukan yang relevan. Ukuran huruf $12 \mathrm{pt}$ dengan spasi 1,5.

Data hasil eksperimen yang diambil dalam penelitian ini adalah kuat arus (I) dan tegangan (V) yang kemudian akan dihitung untuk menentukan besaran daya yang dikeluarkan oleh generator turbin dan efisiensi turbin. Berdasarkan pengujian, maka diperoleh data tegangan (V) dan arus (I) pada besaran output yang dikeluarkan oleh generator. Hasil data tegangan dan arus dapat dilihat pada Tabel 1 dan 2.

Tabel 1. Data Hasil Penelitian Output Tegangan (V) dan Arus (I) pada Turbin Kinetik Poros Vertikal

\begin{tabular}{|c|c|c|c|c|c|c|c|}
\hline \multirow{3}{*}{$\begin{array}{c}\text { Variasi } \\
\text { Sudut } \\
\text { Pengarah } \\
\text { an Aliran }\end{array}$} & \multirow{3}{*}{$\begin{array}{c}\text { Perco } \\
\text { baan } \\
\text { ke- }\end{array}$} & \multicolumn{6}{|c|}{ Debit Aliran (Q) } \\
\hline & & \multicolumn{2}{|c|}{$50 \mathrm{~m}^{3} / \mathrm{jam}$} & \multicolumn{2}{|c|}{$70 \mathrm{~m}^{3} / \mathrm{jam}$} & \multicolumn{2}{|c|}{$90 \mathrm{~m}^{3} / \mathrm{jam}$} \\
\hline & & $\begin{array}{c}\mathrm{V} \\
\text { (Volt) }\end{array}$ & $\begin{array}{c}\text { I } \\
\text { (Ampere) }\end{array}$ & $\begin{array}{c}\mathrm{V} \\
\text { (Volt) }\end{array}$ & I (Ampere) & $\begin{array}{c}\mathrm{V} \\
\text { (Volt) }\end{array}$ & I (Ampere) \\
\hline \multirow{3}{*}{ Sudut $5^{0}$} & 1 & 0,74 & 0,96 & 0,81 & 1,12 & 0,92 & 1,24 \\
\hline & 2 & 0,76 & 0,93 & 0,83 & 1,09 & 0,89 & 1,20 \\
\hline & 3 & 0,80 & 0,99 & 0,86 & 1,14 & 0,90 & 1,21 \\
\hline \multicolumn{2}{|c|}{ Rata-rata } & 0,77 & 0,96 & 0,83 & 1,12 & 0,90 & 1,22 \\
\hline \multirow{3}{*}{ Sudut $10^{\circ}$} & 1 & 0,82 & 1,11 & 0,87 & 1,18 & 0,98 & 1,29 \\
\hline & 2 & 0,80 & 1,19 & 0,92 & 1,19 & 0,96 & 1,28 \\
\hline & 3 & 0,86 & 1,10 & 0,85 & 1,21 & 0,97 & 1,32 \\
\hline \multicolumn{2}{|c|}{ Rata-rata } & 0,83 & 1,13 & 0,88 & 1,19 & 0,97 & 1,30 \\
\hline \multirow{3}{*}{ Sudut $15^{0}$} & 1 & 0,96 & 1,18 & 0,95 & 1,26 & 1,11 & 1,33 \\
\hline & 2 & 0,93 & 1,19 & 0,99 & 1,24 & 1,13 & 1,36 \\
\hline & 3 & 1,02 & 1,24 & 1,06 & 1,23 & 1,16 & 1,35 \\
\hline \multicolumn{2}{|c|}{ Rata-ra } & 0,97 & 1,20 & 1,00 & 1,24 & 1,13 & 1,35 \\
\hline
\end{tabular}

Tabel 2. Data Hasil Penelitian Output Tegangan (V) dan Arus (I) pada Turbin Kinetik Poros Horizontal

\begin{tabular}{|c|c|c|c|c|c|c|c|}
\hline \multirow{3}{*}{$\begin{array}{c}\text { Variasi } \\
\text { Sudut } \\
\text { Pengarah } \\
\text { an Aliran }\end{array}$} & \multirow{3}{*}{$\begin{array}{c}\text { Perco } \\
\text { baan } \\
\text { ke- }\end{array}$} & \multicolumn{6}{|c|}{ Debit Aliran (Q) } \\
\hline & & \multicolumn{2}{|c|}{$50 \mathrm{~m} 3 /$ jam } & \multicolumn{2}{|c|}{$70 \mathrm{~m} 3 /$ jam } & \multicolumn{2}{|c|}{$90 \mathrm{~m} 3 /$ jam } \\
\hline & & $\begin{array}{c}\text { V } \\
\text { (Volt) }\end{array}$ & $\begin{array}{c}\text { I } \\
\text { (Ampere) }\end{array}$ & $\begin{array}{c}\text { V } \\
\text { (Volt) }\end{array}$ & I (Ampere) & $\begin{array}{c}\text { V } \\
\text { (Volt) }\end{array}$ & I (Ampere) \\
\hline \multirow{3}{*}{ Sudut $5^{0}$} & 1 & 0,80 & 0,98 & 0,87 & 1,12 & 0,98 & 1,32 \\
\hline & 2 & 0,78 & 1,04 & 0,90 & 1,09 & 0,99 & 1,30 \\
\hline & 3 & 0,82 & 1,02 & 0,89 & 1,14 & 1,04 & 1,29 \\
\hline \multicolumn{2}{|c|}{ Rata-rata } & 0,80 & 1,01 & 0,89 & 1,12 & 1,00 & 1,30 \\
\hline \multirow{3}{*}{ Sudut $10^{\circ}$} & 1 & 0,88 & 1,18 & 0,87 & 1,21 & 1,05 & 1,35 \\
\hline & 2 & 0,90 & 1,20 & 0,92 & 1,24 & 1,03 & 1,36 \\
\hline & 3 & 0,93 & 1,17 & 0,85 & 1,27 & 1,08 & 1,34 \\
\hline \multicolumn{2}{|c|}{ Rata-rata } & 0,90 & 1,18 & 0,88 & 1,24 & 1,05 & 1,35 \\
\hline \multirow{3}{*}{ Sudut $15^{0}$} & 1 & 0,96 & 1,18 & 0,95 & 1,30 & 1,14 & 1,40 \\
\hline & 2 & 0,93 & 1,19 & 0,99 & 1,32 & 1,17 & 1,42 \\
\hline & 3 & 1,02 & 1,24 & 1,06 & 1,35 & 1,13 & 1,39 \\
\hline \multicolumn{2}{|c|}{ Rata-rata } & 0,97 & 1,20 & 1,00 & 1,32 & 1,15 & 1,40 \\
\hline
\end{tabular}


Setelah menyelesaikan pengujian dan pengolahan data, maka diperoleh datadata antara lain, debit air, daya air, daya generator, dan efisiensi. Daya air yang diperoleh berbeda-beda, hal ini disebabkan karena berbeda-bedanya debit air yang diberikan. Dimulai dari debit air 50 m3/jam (Q1), 70 m3/jam (Q2), 90 m3/jam (Q3). Semakin besar debit air, maka daya air yang tersedia juga semakin besar. Daya air (input) inilah yang kemudian dimanfaatkan untuk memutar roda air sehingga menghasilkan putaran. Kemudian putaran roda air akan diteruskan ke generator melalui puli untuk menghasilkan daya listrik.

Daya listrik generator yang dihasilkan sangat dipengaruhi oleh putaran roda air, semakin banyak putaran roda air yang dihasilkan maka kuat arus yang dihasilkan semakin besar pula sehingga daya listrik juga semakin besar. Kinerja roda air atau biasa disebut dengan efisiensi $(\eta)$ didapat dari perbandingan antara daya listrik yang dihasilkan oleh generator dengan daya air yang tersedia. Dari hasil pengamatan diketahui bahwa efisiensi $(\eta)$ tidak berbanding lurus terhadap daya yang dihasilkan oleh generator.Berdasarkan data kuat arus (I) dan tegangan (V) yang diperoleh dalam percobaaan, maka selanjutnya dihitung daya output dan efisiensi turbin yang dapat dilihat pada Tabel 3 dan Tabel 4.

Tabel 3. Data Hasil Perhitungan Output Daya (P) dan Efisiemsi ( $\eta$ ) pada Turbin Kinetik Poros Vertikal

\begin{tabular}{|c|c|c|c|c|c|c|c|}
\hline \multirow{3}{*}{$\begin{array}{c}\text { Variasi } \\
\text { Sudut } \\
\text { Pengarahan } \\
\text { Aliran }\end{array}$} & \multirow{3}{*}{$\begin{array}{c}\text { Perco } \\
\text { baan } \\
\text { ke- }\end{array}$} & \multicolumn{6}{|c|}{ Debit Aliran (Q) } \\
\hline & & \multicolumn{2}{|c|}{$50 \mathrm{~m}^{3} /$ jam } & \multicolumn{2}{|c|}{$70 \mathrm{~m}^{3} / \mathrm{jam}$} & \multicolumn{2}{|c|}{$90 \mathrm{~m}^{3} / \mathrm{jam}$} \\
\hline & & $\begin{array}{c}\text { Daya } \\
\text { (Watt) }\end{array}$ & $\begin{array}{c}\text { Efisiensi } \\
(\%)\end{array}$ & $\begin{array}{c}\text { Daya } \\
\text { (Watt) }\end{array}$ & $\begin{array}{c}\text { Efisiensi } \\
(\%)\end{array}$ & $\begin{array}{c}\text { Daya } \\
\text { (Watt) }\end{array}$ & $\begin{array}{c}\text { Efisiensi } \\
(\%)\end{array}$ \\
\hline \multirow{3}{*}{ Sudut $5^{0}$} & 1 & 0,71 & 10 & 0,91 & 9 & 1,14 & 9 \\
\hline & 2 & 0,71 & 10 & 0,90 & 9 & 1,07 & 9 \\
\hline & 3 & 0,79 & 11 & 0,98 & 10 & 1,09 & 9 \\
\hline \multicolumn{2}{|c|}{ Rata-rata } & 0,74 & 11 & 0,93 & 10 & 1,10 & 9 \\
\hline \multirow{3}{*}{ Sudut $10^{\circ}$} & 1 & 0,91 & 13 & 1,03 & 11 & 1,26 & 10 \\
\hline & 2 & 0,95 & 14 & 1,09 & 11 & 1,23 & 10 \\
\hline & 3 & 0,95 & 14 & 1,03 & 11 & 1,28 & 10 \\
\hline \multicolumn{2}{|c|}{ Rata-rata } & 0,94 & 13 & 1,05 & 11 & 1,26 & 10 \\
\hline \multirow{3}{*}{ Sudut $15^{\circ}$} & 1 & 1,13 & 16 & 1,20 & 12 & 1,48 & 12 \\
\hline & 2 & 1,11 & 16 & 1,23 & 13 & 1,54 & 12 \\
\hline & 3 & 1,26 & 18 & 1,30 & 13 & 1,57 & 13 \\
\hline \multicolumn{2}{|c|}{ Rata-rata } & 1,17 & 17 & 1,24 & 13 & 1,53 & 12 \\
\hline
\end{tabular}

Tabel 4. Data Hasil Perhitungan Output Daya (P) dan Efisiemsi ( $\eta$ ) pada Turbin Kinetik Poros Horizontal

\begin{tabular}{|c|c|c|c|c|c|c|c|}
\hline \multirow{3}{*}{$\begin{array}{c}\text { Variasi } \\
\text { Sudut } \\
\text { Pengarahan } \\
\text { Aliran }\end{array}$} & \multirow{3}{*}{$\begin{array}{c}\text { Perco } \\
\text { baan } \\
\text { ke- }\end{array}$} & \multicolumn{6}{|c|}{ Debit Aliran (Q) } \\
\hline & & \multicolumn{2}{|c|}{$50 \mathrm{~m}^{3} / \mathrm{jam}$} & \multicolumn{2}{|c|}{$70 \mathrm{~m}^{3} / \mathrm{jam}$} & \multicolumn{2}{|c|}{$90 \mathrm{~m}^{3} / \mathrm{jam}$} \\
\hline & & $\begin{array}{c}\text { Daya } \\
\text { (Watt) }\end{array}$ & $\begin{array}{c}\text { Efisiens } \\
\text { i }(\%)\end{array}$ & $\begin{array}{c}\text { Daya } \\
\text { (Watt) }\end{array}$ & $\begin{array}{c}\text { Efisiensi } \\
(\%)\end{array}$ & $\begin{array}{c}\text { Daya } \\
\text { (Watt) }\end{array}$ & $\begin{array}{c}\text { Efisiensi } \\
(\%)\end{array}$ \\
\hline \multirow{3}{*}{ Sudut $5^{0}$} & 1 & 0,78 & 11 & 1,04 & 11 & 1,29 & 10 \\
\hline & 2 & 0,81 & 12 & 1,03 & 11 & 1,29 & 10 \\
\hline & 3 & 0,84 & 12 & 1,09 & 11 & 1,34 & 11 \\
\hline \multicolumn{2}{|c|}{ Rata-rata } & 0,81 & 12 & 1,05 & 11 & 1,31 & 10 \\
\hline \multirow{2}{*}{ Sudut $10^{\circ}$} & 1 & 1,04 & 15 & 1,09 & 11 & 1,42 & 11 \\
\hline & 2 & 1,08 & 16 & 1,13 & 12 & 1,40 & 11 \\
\hline
\end{tabular}




\begin{tabular}{|c|c|c|c|c|c|c|c|}
\hline & 3 & 1,09 & 16 & 1,12 & 12 & 1,45 & 12 \\
\hline \multicolumn{2}{|c|}{ Rata-rata } & 1,07 & 15 & 1,11 & 12 & 1,42 & 11 \\
\hline \multirow{3}{*}{ Sudut $15^{\circ}$} & 1 & 1,23 & 18 & 1,24 & 13 & 1,60 & 13 \\
\hline & 2 & 1,28 & 18 & 1,31 & 13 & 1,66 & 13 \\
\hline & 3 & 1,25 & 18 & 1,43 & 15 & 1,57 & 13 \\
\hline \multicolumn{2}{|c|}{ Rata-rata } & 1,25 & 18 & 1,32 & 14 & 1,61 & 13 \\
\hline
\end{tabular}

\section{Hubungan Debit Air dengan Daya Output pada Tiap Sudut Aliran}

Berikut disajikan grafik yang menunjukkan hubungan antara debit air dengan daya yang dihasilkan oleh generator (daya output) poros vertikal dan horizontal pada masing-masing sudut pengarah aliran (Gambar 3).

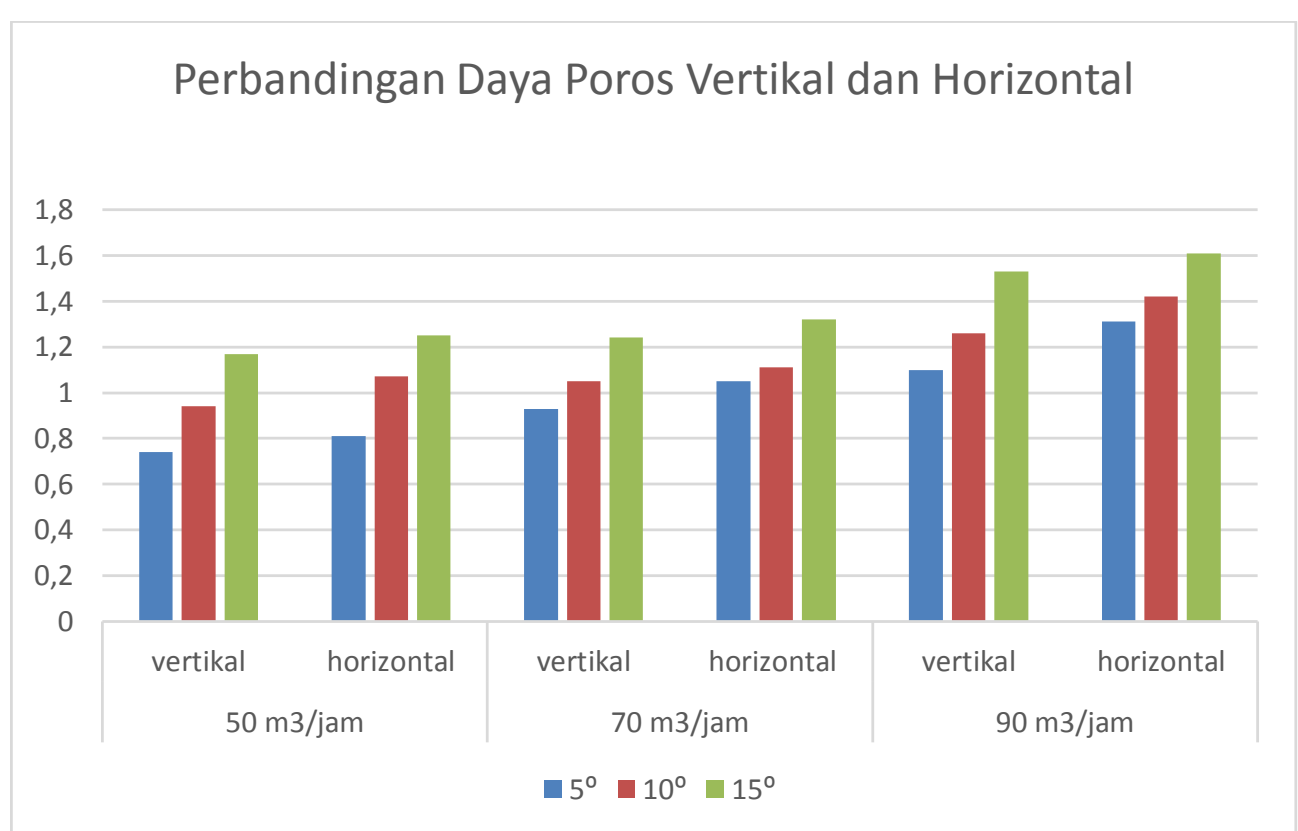

Gambar 3. Grafik Perbandingan Daya Output pada Turbin Kinetik Poros Vertikal dan Horizontal

Grafik menunjukkan hubungan antara $\mathrm{Q}=$ perubahan debit (m3/jam) terhadap Pgen $=$ Daya listrik yang dihasilkan (Watt). Dimana debit aliran air (Q) merupakan laju aliran air (dalam bentuk volume air) yang melewati suatu penampang atau saluran tiap satu satuan waktu. Nilai dari Pgen dapat diperoleh dengan menggunakan persamaan:

Pgen $=$ V . I

Dimana :

$\mathrm{P}=$ daya listrik yang dihasilkan (watt)

$\mathrm{V}=$ beda potensial $(\mathrm{v})$

$\mathrm{I}=$ kuat arus $(\mathrm{A})$

Dapat kita lihat bahwa grafik tersebut di atas menunjukkan bahwa semakin besar perubahan debit aliran maka daya listrik yang dihasikan akan semakin besar pula, namun ketika kinerja roda air sudah mencapai titik maksimumnya maka daya listrik akan mengalami penurunan akibat semakin besarnya pembebanan yang diberikan terhadap roda air. Sehingga dalam grafik akan membentuk sebuah garis 
setengah parabola. Selain itu beban lampu juga sangat mempengaruhi kinerja roda air. Seperti terlihat pada grafik di atas dimana semakin banyak beban yang diberikan maka akan menurunkan kinerja dari roda air. Berdasarkan grafik, dapat diketahui bahwa daya yang dihasilkan pada poros turbin kinetik horizontal memiliki daya yang sedikit lebih besar dibandinkan dengan poros horizontal $( \pm 0,1$ Watt).

\section{Hubungan Debit Air dengan Efisiensi Turbin pada Tiap Sudut Aliran}

Berikut disajikan grafik yang menunjukkan hubungan antara debit air dengan efisiensi turbin kinetik poros vertikal dan horizontal pada masing-masing sudut pengarah aliran (Gambar 4).

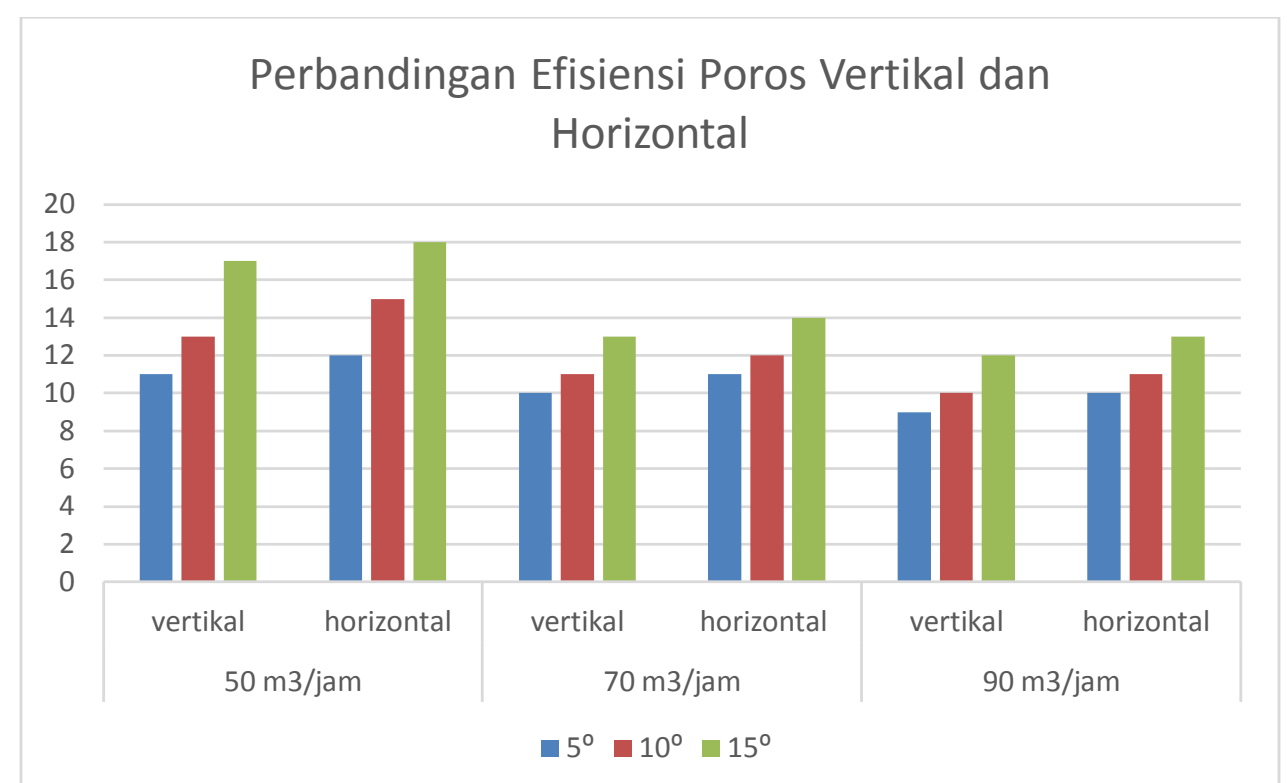

Gambar 4. Grafik Perbandingan Efisiensi pada Turbin Kinetik Poros Vertikal dan Horizontal

Berdasarkan grafik di atas yang menunjukkan hubungan antara efisiensi total $(\%)$ dengan debit (m3/s). Debit aliran air (Q) merupakan laju aliran air (dalam bentuk volume air) yang melewati suatu penampang atau saluran tiap satu satuan waktu. Untuk mendapatkan nilai dari efisiensi total, dapat digunakan persamaan sebagai berikut :

$$
\eta=\frac{P_{t}}{\frac{1}{2} Q \cdot \rho} \times 100 \%
$$

Dimana

$\eta=$ efisiensi turbin (\%)

$\mathrm{Pt}=$ daya yang dihasilkan turbin (Watt)

$\mathrm{Q}=$ debit aliran air $(\mathrm{m} 3 / \mathrm{s})$

$\rho=$ massa jenis air $(\mathrm{kg} / \mathrm{m} 3)$

Grafik di atas menunjukkan hubungan bahwa semakin besar debit alirannya maka efisiesi yang dihasilkan juga akan semakin kecil, hal ini juga dipengaruhi oleh besarnya pembebanan yang diberikan. Efisiensi tertinggi yaitu sebesar $18 \%$ terjadi 
pada debit aliran $50 \mathrm{~m} 3 / \mathrm{jam}$ dengan sudut pengarah aliran sebesar $15^{\circ}$. Efisiensi terendah sebesar $10 \%$ terjadi ketika turbin dialiri debit air sebesar $90 \mathrm{~m} 3 / \mathrm{jam}$ dengan sudut pengarah aliran $5^{\circ}$.

\section{KESIMPULAN}

Berdasarkan hasil analisis data, daya output yang dihasilkan turbin maksimal sebesar 1,53 Watt terjadi pada debit $90 \mathrm{~m} 3 /$ jam dengan sudut pengarah aliran $15^{\circ}$. Selain itu, daya yang dihasilkan turbin sebanding dengan debit air yang digunakan. Semakin besar debit air maka semakin besar pula daya yang dihasilkan. Efisiensi tertinggi yaitu sebesar $18 \%$ terjadi pada debit aliran $50 \mathrm{~m} 3 / \mathrm{jam}$ dengan sudut pengarah aliran sebesar $15^{\circ}$. Berbeda dengan hubungan antara debit air dengan daya, hubungan antara efisiensi dengan debit air merupakan hubungan terbalik, Semakin kecil debit aliran, maka semakin kecik efisiensi yang dihasilkan turbin. Turbin dengan poros horizontal memiliki nilai daya dan efisiensi yang sedikit lebih besar jika dibandingan dengan turbin poros vertikal.

\section{DAFTAR PUSTAKA}

[1] Direktorat Konstruksi dan Energi Baru Terbarukan (DKEBT), 2013. PT. PLN (Persero)

[2] Pietersz, Richard.,Soenoko, Rudy.,Wahyudi, Slamet. 2013. Pengaruh Jumlah Sudu terhadap Optimalisasi Kinerja Turbin Kinetik Roda Tunggal. Jurnal Rekayasa Mesin, Vol.4, No.2 Tahun 2013: 93-100

[3] Asroful Anam. Rudy Soenoko. Denny Widhiyanuriyawan. 2013. Pengaruh Variasi Sudut Input Sudu Mangkok Terhadap Kinerja Turbin Kinetik. Universitas Brawijaya Malang.

[4] Yani, Ahmad,. Mihdar,. Erianto, Rudi. 2016. Pengaruh Variasi Bentuk Sudu Terhadap Kinerja Turbin Air Kinetik Sebagai Alternatif Pembangkit Listrik Daerah Pedesaan. Jurnal Turbo 5 (1).

[5] Ohoirenan. W, Wahyudi. S, dan Sutikno, D,. 2012. Pengaruh Variasi Jumlah Sudu Terhadap Kinerja Turbin Kinetik Roda Tunggal. Prosiding Seminar Nasional Science, Engineering and Technology, Brawijaya Malang.

[6] Warsito, Sri Wahyudi, D. dan Wildan Khoiron. 2011. Realisasi dan Analisa Sumber Energi Baru Terbarukan Nanohidro Dari aliran air Berdebit kecil. Jurnal Material dan Energi Indonesia, Volume 01 Nomor 01. 